Original Research Paper

\title{
Study of dug well water quality in Labuan Bajo, Indonesia
}

\author{
Daniel Wolo ${ }^{1}$, Anna S. Rahmawati ${ }^{1}$, Melania Priska ${ }^{2}$, Insar Damopolii ${ }^{3}$ \\ ${ }^{1}$ Department of Physics Education, Universitas Flores, Flores, Indonesia; \\ ${ }^{2}$ Department of Biology Education, Universitas Flores, Flores, Indonesia; \\ ${ }^{3}$ Department of Biology Education, UniversitasPapua ${ }_{3}$ Manokwari, Indonesia;
}

\author{
Article History \\ Received : October $24^{\text {th }}, 2020$ \\ Revised : November $09^{\text {th }}, 2020$ \\ Accepted : November $15^{\text {th }}, 2020$ \\ Published : November $21^{\text {th }}, 2020$ \\ *Corresponding Author: \\ Daniel Wolo, \\ Department of Physics Education, \\ Universitas Flores, Flores, \\ Indonesia; \\ Email:dewolochem@gmail.com
}

\begin{abstract}
The dug well water quality in community settlements needs assessment to ensure its quality. The water has to meet the required physical, chemical, and bacteriological standards. This initial research aimed to determine the dug well water quality in Kampung Ujung, Komodo District, Labuan Bajo City, West Manggarai Regency in September 2019. The research method was used survey and laboratory. The two dug well was taken used a purposive sampling technique. The test parameters include temperature, turbidity, pH, smell, Total Suspended Solid (TSS), sulfate, Total Dissolved Solid (TDS), nitrate, nitrite, Total Hardness, Dissolved Oxygen (DO), nitrogen ammonia, total coliforms, and Escherichia coli. The analysis physically, chemically, and biologically of two dug well water samples were had done examined. The result showed that the parameters of TDS, nitrate, nitrite, E. coli, and DO exceed the Class I Water Quality Standard. The research concluded that the quality of both dug well water in the Kampung Ujung Labuan Bajo area was not suitable for use as material raw drinking water. Furthermore, the government should provide other water sources such as the addition of storage tanks for raw water, so that people do not entirely depend on dug well water.
\end{abstract}

Keywords: Dug well; water quality; contamination; Labuan Bajo; drinking water

\section{Introduction}

Kampung Ujung is one of the areas included in the Komodo District, Labuan Bajo City, West Manggarai Regency. In recent years, the increasing population and tourism activities in Kampung Ujung have impacted environmental quality changes, particularly the aquatic environment.The development of tourism infrastructures such as culinary parks, minimarkets, hotels, and malls can contribute to groundwater pollution (Igusman \& Purwadi, 2014), exceptionally safe drinking water (Uprety et al., 2020).

Based on field monitoring results, the Kampung Ujung community's settlement pattern is center on one area, and the practice is irregular. Some of the houses are adjacent to hotels, cafes, or restaurants that are recentlybuilt. With the increase in population and tourism activities, it will demand even greater water needs. The increased of human activity, that mainly due to tourism sector developmment, can result in environmental degradation, such as decreasing groundwater quality (Putu et al., 2018). Human behavior affects the quality of the environment (Mardhia \& Abdullah, 2018).

Meanwhile, the water sources used daily (for bathing, washing, latrines) and the tourism industry aresourced from groundwater sources and water companies. Based on interviews with residents who often use dug well water, it is found that well water cannot be used in certain seasons because it smelly and tastes very salty. The dug wells in Kampung Ujung are shallow well $(<20 \mathrm{~m})$, cheap and easily made. Therefore, they are widely used by the community. However, dug wells have a high risk due to physical and chemical, and bacteriological pollution(Kot, Baranowski, \& Rybak, 2000; Latief, Wahjoedi, Sugiharto, \& Suparman, 2015).

Drinking water has to meet the required physical, chemical, and bacteriological standards. The usage of drinking water that doesn't comply with quality standards can cause health problems. Shallow groundwater in dug wells has the potential to absorb 
pollutants(Wardani, 2017). These pollutants come from the seepage of surface water, such as rainwater, accumulated with well water. In densely populated settlements, groundwater pollution is also caused by the lack of available land for making septic tanks, so that pollutants will flow with rainwater to water bodies(Putra, 2018).

Apart from human activities, several factors that affect water quality are slope, geological strata, and rainfall (Aryasa, Risky, \& Artaningsih, 2019). The location of Kampung Ujung that located near the beach also causes seawater intrusion. The activities of hotels, restaurants, and culinary parks can produce organic waste. If the processing is not controlled, it will cause decay of organic waste in waterways to become smelly and a den of disease (Manurung, Ivansyah, \& Nurhasanah, 2017). Poor management of landfills affects water quality(Finmeta, Bunyani, \& Naisanu, 2020; Luo et al., 2019).

Anticipating groundwater pollution levels need an action through regular and continuous monitoring (Istipsaroh, Laili, \& Zayadi, 2016; Luo et al., 2019). The first action that have to be carried out is by collecting initial data, especially data on monitored water quality. This data collection is through a water quality analysis study either in the field (in-situ) or in the laboratory (ex-situ). By monitoring water quality, it is a hope that they can detect and measure a pollutant's effect due to increased human activity and know a general picture of water quality in a place. This initial research aimed to determine the dug well water quality in Kampung Ujung, Komodo District, Labuan Bajo City, West Manggarai Regency.

\section{Materials and Methods}

\section{Time and locationof research}

This research was conducted in dug well water at two sampling locations inKampung Ujung residents' residential area, Labuan Bajo. The dug wells in the Ujung Village have a part like cover of the well lip made of used zinc, well walls, well floors, sewage and sewage equipped with bucket hoist and pump reel.

This research had been carried out in September 2019.The sampling determination technique used a purposive sampling technique based on considering that well water is often using as drinking water, bathing, washing, the location of wells from other polluting sources, and well owners are willing to sample their wells.

Based on observations, there are five dug wells in the Kampung Ujung. The community used two of the five dug wells. These two wells are located in the middle of a community settlement and are still being used by several families. The first dug well was located in the middle of dense settlements. There were activities around the well for washing dishes, bathrooms, and runoff water from the housing. The dug well distance to the beach was about 75 meters. The first dug well's coordinates were 8.488537 , $119.877039 / 8^{\circ} 29^{\prime} 18.7$ "S $119^{\circ} 52 ' 37.3^{\prime \prime}$ E. The second dug well was used for about 4-5 families. The distance from the well to the beach was about 100 meters. The distance from the first well to the second well was about 100 meters. The first dug well's coordinates were 8.489210, $119.876487 / 8^{\circ} 29^{\prime} 21.2$ "S $119^{\circ} 52 ' 35.4 " \mathrm{E}$.

\section{Sample collection and analysis}

Water sample was taken in the morning before residents' activities. The water sample was put in a sterile black bottle. The bottle was also rinsed three times with the water sample. The parameters observed in this research included temperature, turbidity, pH, smell, Total Suspended Solid (TSS), sulfate, Total Dissolved Solids (TDS), nitrate, nitrite, total hardness, Dissolved Oxygen (DO), nitrogen ammonia, total coliforms, and Escherichiacoli. This research emphasizes more on parameters related to safety, acceptance, and function of both water samples. For water quality analysis, it had been done in two ways, namely directly at the location such as temperature and odor and preservation methods carried out in the laboratory by storing samples in tightly closed ice boxes at $4^{\circ} \mathrm{C}+/-2^{\circ} \mathrm{C}$. Table 1 presents all parameters that have been analyzed in this research.

Table 1. Test parameters

\begin{tabular}{|c|c|c|}
\hline Parameter & Unit & Method Specifications \\
\hline Temperature & ${ }^{\circ} \mathrm{C}$ & Thermometric \\
\hline Smell & & Organoleptic \\
\hline Turbidity & NTU & Turbidimetry \\
\hline $\begin{array}{l}\text { Total } \\
\text { Dissolved } \\
\text { Solid (TDS) }\end{array}$ & $\mathrm{mg} / \mathrm{L}$ & $\begin{array}{l}\text { SNI 06-6989.27-2005 } \\
\text { Method of gravimetric } \\
\text { Total Dissolved Solids } \\
\text { level test }\end{array}$ \\
\hline $\begin{array}{l}\text { Total } \\
\text { Suspended } \\
\text { Solid (TSS) }\end{array}$ & $\mathrm{mg} / \mathrm{L}$ & $\begin{array}{l}\text { SNI 06-6989.27-2005 } \\
\text { Method of gravimetric } \\
\text { Total Dissolved Solids } \\
\text { level test }\end{array}$ \\
\hline $\begin{array}{l}\text { Total } \\
\text { Hardness }\end{array}$ & $\mathrm{mg} / \mathrm{L}$ & $\begin{array}{l}\text { Spectrophotometric } \\
\text { Hach }\end{array}$ \\
\hline $\mathrm{pH}$ & & $\begin{array}{l}\text { SNI 06-6989.11-2004 } \\
\text { The method of testing } \\
\text { the degree of acidity } \\
\text { using a pH meter }\end{array}$ \\
\hline Nitrate & $\mathrm{mg} / \mathrm{L}$ & SpectrophotometricHach \\
\hline Nitrite & $\mathrm{mg} / \mathrm{L}$ & $\begin{array}{l}\text { Spectrophotometric } \\
\text { Hach }\end{array}$ \\
\hline Sulfate & $\mathrm{mg} / \mathrm{L}$ & $\begin{array}{l}\text { Spectrophotometric } \\
\text { Hach }\end{array}$ \\
\hline $\begin{array}{l}\text { Dissolved } \\
\text { Oxygen (DO) }\end{array}$ & $\mathrm{mg} / \mathrm{L}$ & $\begin{array}{l}\text { SNI 06-6989.14-2004 } \\
\text { Method of gravimetric } \\
\text { Total Dissolved Solids } \\
\text { level test }\end{array}$ \\
\hline
\end{tabular}


Daniel Wolo et al. (2020). Jurnal Biologi Tropis, 20 (3): 432 - 437 DOI: http://dx.doi.org/10.29303/jbt.v20i3.2135

\begin{tabular}{|l|c|l|}
\hline $\begin{array}{l}\text { Nitrogen } \\
\text { ammonia }\end{array}$ & $\mathrm{mg} / \mathrm{L}$ & $\begin{array}{l}\text { Spectrophotometric } \\
\text { Hach }\end{array}$ \\
\hline Totalcoliforms & $\begin{array}{c}\text { CFU/100 } \\
\mathrm{mL}\end{array}$ & ALT \\
\hline $\begin{array}{l}\text { Number of } E . \\
\text { coli }\end{array}$ & $\begin{array}{c}\text { CFU/100 } \\
\mathrm{mL}\end{array}$ & ALT \\
\hline
\end{tabular}

\section{Results and Discussion}

The dug well water quality measurement

The results of this research reveal how the water quality of dug well in KampungUjung. Our research was conducted in September 2019, where the level of rainfall in the city of Labuan Bajo began to decline. The reason for choosing Kampung Ujung is because this area is one of the most visited culinary tourism destinations. Besides that, there are residential areas which are quite dense. The test results of groundwater samples (dug wells) show that several parameters exceed the government's quality standards: TDS, DO, nitrate and nitrite, and nitrogen ammonia parameters almost exceed the standard. The results of the research are presented in Table 2. solus per aqua, and public baths (Permen Republik Indonesia, 2001).

Table 2.Results of dug well water quality measurement in Kampung Ujung

\begin{tabular}{|c|c|c|c|c|c|c|}
\hline \multirow{2}{*}{ No } & \multirow{2}{*}{ Parameter } & \multirow{2}{*}{ Unit } & \multicolumn{2}{|c|}{ Test result } & \multirow{2}{*}{$\begin{array}{c}\text { Quality } \\
\text { standard }\end{array}$} & \multirow{2}{*}{ Annotation } \\
\hline & & & $1^{\text {st }}$ Well & $2^{\text {nd }}$ Well & & \\
\hline 1 & Temperature & ${ }^{\circ} \mathrm{C}$ & 29.94 & 29,52 & $\begin{array}{c}\text { Air } \\
\text { Temperature } \\
\pm 3 \\
\end{array}$ & \multirow{5}{*}{$\begin{array}{l}\text { Quality standard of } \\
\text { PERMENKES No. } 32 \text { of the } \\
\text { year } 2017 \text { regarding } \\
\text { environmental health quality } \\
\text { standards and water health } \\
\text { requirements for hygiene } \\
\text { purposes sanitation, swimming } \\
\text { pools, solus per aqua, and } \\
\text { public baths }\end{array}$} \\
\hline 2 & Smell & & Odorless & Odorless & & \\
\hline 3 & Turbidity & NTU & 0,47 & 0,72 & 25 & \\
\hline 4 & TDS & $\mathrm{mg} / \mathrm{L}$ & 13115 & 1736 & 1000 & \\
\hline 5 & TSS & $\mathrm{mg} / \mathrm{L}$ & 0,02 & 0,02 & 50 & \\
\hline 6 & Total Hardness & $\mathrm{mg} / \mathrm{L}$ & 0,39 & 0,75 & 500 & \multirow{7}{*}{$\begin{array}{l}\text { PP No. } 82 \text { of the year } 2001 \\
\text { concerning the management of } \\
\text { water quality and water } \\
\text { pollution control }\end{array}$} \\
\hline 7 & $\mathrm{pH}$ & & 6,9 & 7,5 & $6,5-8,5$ & \\
\hline 8 & Nitrate & $\mathrm{mg} / \mathrm{L}$ & 12 & 8 & 10 & \\
\hline 9 & Nitrite & $\mathrm{mg} / \mathrm{L}$ & 0,4 & 2,2 & 1 & \\
\hline 10 & Sulfate & $\mathrm{mg} / \mathrm{L}$ & 62 & 54 & 400 & \\
\hline 11 & DO & $\mathrm{mg} / \mathrm{L}$ & 3,3 & 3,9 & 4 & \\
\hline 12 & Nitrogen ammonia & $\mathrm{mg} / \mathrm{L}$ & 0,45 & 0,01 & 0,5 & \\
\hline 13 & Totalcoliforms & $\begin{array}{c}\text { CFU/ } \\
100 \mathrm{~mL}\end{array}$ & 29 & 11 & 50 & \multirow{2}{*}{$\begin{array}{l}\text { Quality } \\
\text { standardPERMENKES } \\
\text { No.32 of the year } 2017\end{array}$} \\
\hline 14 & Number of $E$. coli & $\begin{array}{c}\text { CFU/10 } \\
0 \mathrm{~mL}\end{array}$ & 7 & 7 & 0 & \\
\hline
\end{tabular}

Source: Environmental Laboratory, Environmental Service, Ende Regency Government, 2019

Note: $\square$ is a value that exceeds the maximum allowable threshold.

\section{Physical parameters}

Based on Table 2, the parameters of Total Dissolved Solids (TDS) are dissolved materials that have a diameter range from $10-6 \mathrm{~mm}$ to $10-3 \mathrm{~mm}$ (including colloids). The laboratory analysis results showed that TDS content of the first sample was 13 times higher than the standard set. In the second sample, the number of TDS also exceeds the standard, 1736. It is almost two times the standard. TDS is one of the nine water quality criteria(Tripathi \& Singal, 2019). TDS is caused by inorganic materials, which are commonly found in areas close to water. The Kampung Ujung area is close to the sea, one of these inorganic ions resources. Some of these ions can become main ion groups such as sodium, calcium, sulfate, bicarbonate, or secondary ion groups such as iron, potassium, carbonate, nitrate, fluoride ions. The first sample is in the medium / brackish salinity group base on the TDS concentration obtained. The second sample had a slightly salty/brackish salinity level. The high TDS is probably due to rock weathering, runoff from the soil, and anthropogenic influences / human activities in domestic waste and the tourism industry. Even though it is not toxic, the high TDS value can increase water turbidity, which implies a decrease 
in the photosynthesis process in water bodies. Water turbidity will also increase pathogens(Weller et al., 2020).

\section{Chemical Parameters}

The second parameter observed in thisresearch was oxygen (Dissolved Oxygen / DO). Generally, DO decreases with increasing salinity. The first and second samples' analysis shows that the oxygen content is less than the specified water quality standard. DO is one of the parameters for determining quality of water(Varol, 2020). In other research, DOis one of the five main parameters that must be analyzed when we want to determine a certain water standard (Nong, et al., 2020). Apart from the salinity factor, other factors such as the movement of water bodies, photosynthetic activity, and waste also affect the concentration of oxygen. In the first sample, the amount of DO is $3.3 \mathrm{mg} / \mathrm{L}$. The well location is in a dense settlement. The possibility of a lack of photosynthetic activity and high anthropogenic activity (used by around 8-10 families) in the area around the well causes very low dissolved oxygen in the water sample. Whereas in the second sample, dug wells are only used by 4-5 families. The dug well area is wide enough so that the oxygen content is better than the first sample. However, it is still below the standard. Decreasing DO can affect the taste of water, making water not fresh to drink.

Nitrate $\left(\mathrm{NO}_{3}^{-}\right)$, nitrite $\left(\mathrm{NO}_{2}^{-}\right)$, and ammonia $\left(\mathrm{NH}_{4}^{+}\right)$are the minor ion group in the water. The source of these three ions comes from the ammonification process, namely the decay of proteins from living things. Laboratory analysis results show that in the first sample, the nitrate content exceeds the standard. It indicates the occurrence of contamination from human activities and animal feces. High nitrate content can be caused due to inadequate sewage treatment (Singh \& Mosley, 2003). Nitrates that do not comply with WHO standards pose a risk to human digestion and are more susceptible to infant health(Adimalla, 2019).

In the second sample, the detected nitrite levels exceeded the standard standards. The source of nitrite also came from the tourism industry waste or domestic waste. Wastewater installation management, waste collection, and solid waste management need to be done(Luo et al., 2019). nitrite has more toxic properties than nitrate. Consumption of nitrite in humans can disrupt the blood's oxygen-binding process: high nitriteand nitrate content cause methemoglobinemia (Kempster, et al., 1997). The results showed that toddlers are most vulnerable to nitrates through drinking water in the study area (Adimalla \& Wu, 2019). Although it does not exceed the standard, the presence of ammonium ion follows the water sample conditions where the dissolved oxygen value is small or below the standard. This ammonium ion level indicates organic matter contamination from domestic and industrial waste (tourism).

\section{Biological parameters}

The following parameters used to determine the level of groundwater hygiene are the content of totalcoliform and
E. coli. The dug well water samples from the first and second area found that the $E$. coli content exceeded the specified standard. In comparison, total coliform was still below the quality standard. E. coli is a bacterium from the totalcoliforms group that is harmless and is present in human feces. However, the E. coli presence above the consistency standard indicates that human or animal waste has polluted the well water, which most likely contains pathogenic bacteria that are harmful to health. Some of these pathogens can be in groups of bacteria, viruses, protozoa, and helminths. Although the studiedwater met WHO standards, when it is consumed, it is necessary to make an agent kill microbes (Nkansah, et al., 2010). Contaminants such as bacteria, viruses have contaminated water supplies(Singh \& Mosley, 2003). The cause bloody diarrhea in children has been identified from contaminated well water by E. coli(Jackson et al., 1998).The number of $E$. coli found in cattle operation area (Cooley, et al., 2014).

If water sourced is polluted, its quality has to be improved to meet quality standard, in order to keep the health of people who consume the water.Human health may decrease when they drink water from bad quality and unhygienic sources (Mukate, et al., 2019). Based on the result of the study, the quality of groundwater in the Kampung Ujung Labuan Bajo area, is under the quality standard. Therefore, a collaboration between the government and the community is needed to regularly monitor the quality of groundwater in the Kampung Ujung area. The monitoring can be done by checking in the laboratory on three parameters, namely physics, chemistry, and biology, increase public awareness about adequate environmental sanitation starting at the household and residential level.Furthermore, the government should provideother water sources such as the addition of storage tanks for raw water, so that people do not entirely depend on dug well water.

\section{Conclusion}

In Kampung Ujung, Labuan Bajo, do not meet quality standards. A total of five parameters that do not meet the criteria i.e. TDS, DO, nitrate, nitrite, and E. coli. It shows the pollution of shallow water in the Kampung Ujung area. This research concluded that the quality of the two dug wells in the Kampung Ujung Labuan Bajo area is not appropriate for use as rawmaterial for drinking water. Hopefully, there will be further studies related to water quality monitoring using a variety of methods to complete the existing data.

\section{Acknowledgment}

The author would like to thank the Indonesian Ministry of Tourism, the West Manggarai Regency Government, and the Center for Tourism Studies at the University of Flores for this research's financing and 
smoothness through the Sustainable Tourism Monitoring and Observation Program in Labuan Bajo in 2019.

\section{References}

Adimalla, N. (2019). Groundwater Quality for Drinking and Irrigation Purposes and Potential Health Risks Assessment: A Case Study from Semi-Arid Region of South India. Exposure and Health, 11(2), 109-123. https://doi.org/10.1007/s12403018-0288-8

Adimalla, N., \& Wu, J. (2019). Groundwater quality and associated health risks in a semi-arid region of south India: Implication to sustainable groundwater management. Human and Ecological Risk Assessment: An International Journal, 25(12), $191-216$. https://doi.org/10.1080/10807039.2018.1546550

Aryasa, I. W. T., Risky, D. P., \& Artaningsih, N. P. L. J. (2019). Uji Pendahuluan Kualitas Air pada Sumber Mata Air Di Banjar Tanggahan Tengah, Desa Susut Kecamatan Susut. Jurnal Kesehatan Terpadu, 3(2), 76-81. https://doi.org/10.36002/jkt.v3i2.979

Cooley, M., Quiñones, B., Oryang, D., Mandrell, R., \& Gorski, L. (2014). Prevalence of shiga toxin producing Escherichia coli, Salmonella enterica, and Listeria monocytogenes at public access watershed sites in a California Central Coast agricultural region. Frontiers in Cellular and Infection Microbiology, 4, 30. https://doi.org/10.3389/fcimb.2014.00030

Finmeta, A. W., Bunyani, N. A., \& Naisanu, J. (2020). Keberadaan Tempat Pembuangan Akhir Berdampak pada Kualitas Air. Jurnal Biologi Tropis, 20(2), 211. https://doi.org/10.29303/jbt.v20i2.1389

Igusman, I., \& Purwadi, D. D. (2014). Pengaruh Sistem Sanitasi Terhadap Kualitas Air Sumur Dangkal Pada Perumahan Tipe Kecil Di Kota Mojokerto. Rekayasa Teknik Sipil, 3(3), 195-204. Retrieved from

https://jurnalmahasiswa.unesa.ac.id/index.php/rek ayasa-teknik-sipil/article/view/9443

Istipsaroh, Laili, S., \& Zayadi, H. (2016). Uji Kualitas Air Sumur Kelurahan Merjosari Kecamatan Lowokwaru Kota Malang. Biosaintropis, 2(1), 1924. Retrieved from http://biosaintropis.unisma.ac.id/index.php/biosai ntropis/article/view/79/36
Jackson, S. G., Goodbrand, R. B., Johnson, R. P., Odorico, V. G., Alves, D., Rahn, K.,Wilson, J. B., Welch, M. K., \&Khakhria, R. (1998). Escherichia coli $\mathrm{O} 157$ [ratio ]H7 diarrhoea associated with well water and infected cattle on an Ontario farm. Epidemiology and Infection, 120(1), 17-20. https://doi.org/10.1017/S0950268897008479

Kempster, P. L., Van Vliet, H. R., \& Kühn, A. (1997). The need for guidelines to bridge the gap between ideal drinking-water quality and that quality which is practically achievable and acceptable. Water $S A$, 23(2), 163-167. Retrieved from http://www.wrc.org.za/wpcontent/uploads/mdocs/WaterSA_1997_02_1035. PDF

Kot, B., Baranowski, R., \& Rybak, A. (2000). Analysis of mine waters using X-ray fluorescence spectrometry. Polish Journal of Environmental Studies, 9(5), 429-432. Retrieved from http://www.pjoes.com/Keywordmine+water/31541

Latief, A. S., Wahjoedi, Sugiharto, \& Suparman. (2015). Kajian Terhadap Debit dan Kualitas Air Sumur Bor Di Kelurahan Jabungan. TEKNIS, 10(1), 156157. https://doi.org/10.32497/teknis.v10i1.672

Luo, P., Kang, S., Apip, Zhou, M., Lyu, J., Aisyah, S., Binaya, Mishra., Regmi, R. K., \&Nover, D. (2019). Water quality trend assessment in Jakarta: A rapidly growing Asian megacity. PLOS ONE, 14(7),1-

17.https://doi.org/10.1371/journal.pone.0219009

Manurung, M., Ivansyah, O., \& Nurhasanah. (2017). Analisis Kualitas Air Sumur Bor di Pontianak Setelah Proses Penjernihan Dengan Metode Aerasi, Sedimentasi dan Filtrasi. Prisma Fisika, 5(1), 45-50. Retrieved from https://jurnal.untan.ac.id/index.php/jpfu/article/vi ew/19802

Mardhia, D., \& Abdullah, V. (2018). Studi Analisis Kualitas Air Sungai Brangbiji Sumbawa Besar. Jurnal Biologi Tropis, 18(2). https://doi.org/10.29303/jbt.v18i2.860

Mukate, S., Wagh, V., Panaskar, D., Jacobs, J. A., \& Sawant, A. (2019). Development of new integrated water quality index (IWQI) model to evaluate the drinking suitability of water. Ecological Indicators, $\quad$ 348-354. https://doi.org/https://doi.org/10.1016/j.ecolind.20 

19.01 .034

Nkansah, M. A., Boadi, N. O., \& Badu, M. (2010). Assessment of the Quality of Water from HandDug Wells in Ghana. Environmental Health Insights, $4, \quad$ EHI.S3149. https://doi.org/10.4137/EHI.S3149

Nong, X., Shao, D., Zhong, H., \& Liang, J. (2020). Evaluation of water quality in the South-to-North Water Diversion Project of China using the water quality index (WQI) method. Water Research, 178 , 115781. https://doi.org/https://doi.org/10.1016/j.watres.20 20.115781

Peraturan Pemerintah Republik Indonesia, N. 82. (2001). Pengelolaan Kualitas Air Dan Pengendalian Pencemaran Air. Retrieved from https://peraturan.bpk.go.id/Home/Details/53103/p p-no-82-tahun-2001

Putra, C. M. M. (2018). The Physical And Microbiological Quality Of Clean Water In Nanas Sub Village Kediri District Post Natural Phenomena Sinking Wells. Jurnal Kesehatan Lingkungan, $\quad 10(4), \quad 360-367$. https://doi.org/10.20473/jkl.v10i4.2018.36-367

Putu, N., Artini, R., Putu, D., Va, R., Kadek, N., \& Fujiastuti, M. (2018). Penelitian Kualitas Air Sungai Balian, Tabanan, Bali Tahun 2018. Jurnal Kesehatan Terpadu, 2(1), 25-30. https://doi.org/10.36002/jkt.v2i1.443

Singh, S., \& Mosley, L. M. (2003). Trace metal levels in drinking water on Viti Levu, Fiji Islands. The South Pacific Journal of Natural and Applied Sciences, 21(1), 31-34. https://doi.org/10.1071/SP03006

Tripathi, M., \& Singal, S. K. (2019). Use of Principal Component Analysis for parameter selection for development of a novel Water Quality Index: A case study of river Ganga India. Ecological Indicators, $\quad 96, \quad 430-436$. https://doi.org/https://doi.org/10.1016/j.ecolind.20 18.09.025

Uprety, S., Dangol, B., Nakarmi, P., Dhakal, I., Sherchan, S. P., Shisler, J. L.,Jutla, A., Amarasiri, M., Sano, D., \& Nguyen, T. H. (2020). Assessment of microbial risks by characterization of Escherichia coli presence to analyze the public health risks from poor water quality in Nepal. International Journal of Hygiene and Environmental Health,
226 , 113484 .

https://doi.org/https://doi.org/10.1016/j.ijheh.2020 .113484

Varol, M. (2020). Use of water quality index and multivariate statistical methods for the evaluation of water quality of a stream affected by multiple stressors: A case study. Environmental Pollution, 266 , 115417. https://doi.org/https://doi.org/10.1016/j.envpol.20 20.115417

Wardani, Y. S. (2017). Hubungan Konstruksi Sumur Gali dengan Kualitas Air Kabupaten Kebumen Tahun 2017. Buletin Keslingmas, 37(3), 323-331. https://doi.org/10.31983/keslingmas.v36i3.3017

Weller, D., Brassill, N., Rock, C., Ivanek, R., Mudrak, E., Roof, S., ... Wiedmann, M. (2020). Complex Interactions Between Weather, and Microbial and Physicochemical Water Quality Impact the Likelihood of Detecting Foodborne Pathogens in Agricultural Water. Frontiers in Microbiology, 11, 134. https://doi.org/10.3389/fmicb.2020.00134 